\title{
Pojav snežnih skakačev (Collembola) in snežnih bolh (Mecoptera) na snegu na Tebru nad Črno na Koroškem
}

\author{
Dušan JURC ${ }^{*}$, Maja JURC ${ }^{2}$, Gorazd MLINŠEK ${ }^{3}$
}

Dne 26. 2. 2010 je na grebenu proti Dolini smrti pri Matvozu nad Črno na Koroškem vodja KE ZGS Črna Milan Golob opazil velike črne madeže, kot bi bila površina snega prekrita s sajami. Sestavljale so jih drobne črne živali, ki so skakale. Vzorec teh živali je nabral na površini snega na nadmorski višini $850 \mathrm{~m}$, temperatura zraka je bila že nekaj dni nad lediščem in sneg se je topil. V vzorcu smo opazili pripadnike dveh skupin žuželk: nekrilate žuželke ali pražuželke (Apterygota) ter krilate žuželke (Pterygota). V vzorcu je prevladovala prva skupina žuželk in sicer skakači (red Collembola), družina Hypogastruridae in vrsta Hypogastrura socialis Uzel, 1891. Med krilatimi žuželkami smo ugotovili enega predstavnika reda kljunavcev (Mecoptera) iz družine snežnih bolh (Boreidae), in sicer snežno bolho - Boreus westwoodi Hagen, 1866.

\section{Skakači (Collembola)}

Skakači so poleg pršic najpogostejše in najštevilčnejše talne živali, ki imajo pomembno vlogo pri nastanku tal in pri presnovi v tleh. Doslej so opisali okoli 8.000 vrst skakačev, večinoma so to $1-5 \mathrm{~mm}$ dolge živali (redko 0,25 ali do $17 \mathrm{~mm}$ ). Telo skakačev je podolgovato in razdeljeno na tri segmente: enotno glavo, tričleno oprsje s tremi pari nog in petčleni zadek. Na glavi sta dve anteni, ki imata običajno štiri člene, dve očesi iz osmih omatidijev in ustni aparat. Večina vrst ima na zadku poseben organ za skakanje, ki ga imenujejo furka (furca). To je repku podoben privesek, ki je spodvit pod zadek in ga $v$ stalni napetosti drži posebna struktura (retinaculum). Ko je žival ogrožena, se furka sunkovito sproži in vrže skakača v zrak.

V našem zmernem klimatskem pasu so skakači najštevilnejša skupina živali, ki pa jih redko opazimo zaradi njihove majhnosti in značilnega skrivaškega načina življenja v tleh. Njihov ekološki pomen je izjemno velik, sodelujejo pri presnovi organskih odpadkov $\mathrm{v}$ tleh in so hrana drugim živalim. So nepogrešljiv člen pri življenju v tleh in zaradi tega so koristni za človeka. Ko se pojavijo $\mathrm{v}$ velikih skupinah na snegu pogosto povzročijo zaskrbljenost opazovalcev. Tem je treba razložiti, da so skakači popolnoma neškodljivi za človeka, da sodelujejo pri nastanku tal in, da brez njih življenje v tleh ni mogoče.

V celotnem vzorcu živali iz Tebra nad Črno na Koroškem je bila prisotna ena vrsta snežnih skakačev, to je Hypogastrura socialis, ki jo prikazujejo slike 1, 2 in 3, na sliki 4 pa je prikazana shematska risba skakača.

Rod Hypogastrura vključuje približno 160 vrst. Med njimi so znane vrste snežnih skakačev, ki se značilno občasno združujejo v velike agregacije, npr. pri nas na Krasu Hypogastrura socialis ali na topečem se snegu Isotoma saltans ali druge vrste. Nekatere vrste so zelo prilagojene na življenje $\mathrm{v}$ snegu, tam se hranijo $\mathrm{s}$ pelodom in drugim organskim drobirjem, ki ga veter nanese na površino. Običajno so snežni skakači temno obarvani in dobro prenašajo nizke temperature.

Vrsta Hypogastrura socialis je razširjena na celotnem Palearktisu, $v$ nižinah in nižjih gorovjih. Poleti najdemo $\mathrm{v}$ gozdnih tleh in $\mathrm{v}$ opadu samo mladostne (juvenilne) oblike, pozimi pa najdemo odrasle živali na površini talečega se snega. Včasih se zbirajo v velike skupine, ki merijo več $\mathrm{m}^{2}$ in se počasi premikajo $\mathrm{v}$ določeno smer. Vzroki za tako zbiranje v skupine niso pojasnjeni, domnevajo, da se v tleh in opadu namnoženi snežni skakači ob zanje ugodnih ekoloških razmerah premaknejo iz tal na površino snega.

\section{Kljunavci (Mecoptera)}

Predstavniki reda Mecoptera so majhna, a evolucijsko zelo stara skupina žuželk z okoli 550 danes živečimi vrstami. Predstavljajo najstarejše znane fosilne žuželke s starostjo okoli 250 milijonov let. Živijo na vseh kontinentih, tudi $\mathrm{v}$ polarnih predelih Severne Amerike in Evrazije, razen na Antarktiki. Najdemo jih na vlažnih mestih, najpogosteje v rastlinju blizu rek ali potokov, predstavnike družine snežnih bolh pa, kot nakazuje ime, pozimi na snegu. Imajo popolno preobrazbo, ki poteka $\mathrm{v}$ tleh. Ličinke so podobne gosenicam in živijo $\mathrm{v}$ tleh. Imajo zelo trdo glavino kapsulo z obustnimi okončinami, izoblikovanimi v grizalo. Členi oprsja nosijo kratke noge $\mathrm{z}$ reduciranim členjenjem in enim krempljem. Tudi na zadku so kratke nožice in sicer na členih od prvega do osmega. Buba je negibna, ima grizalo. Večinoma samice izležejo jajčeca v vlažno steljo, v tednu ali dveh se izležejo ličinke,ki so prosto živeče, sledi podaljšan stadij predbube, ko se ličinki razvijejo zasnove za krila. Na koncu izkopljejo podolgovato kamrico v zemlji in se v njej zabubijo, ne tvorijo kokona. Odrasle živali so dnevno aktivne živali. Nekatere vrste so znane po zapletenih paritvenih ritualih, ki lahko vključujejo hranjenje partnerja. Adulti živijo okoli enega meseca, zimo preživijo kot jajčeca ali ličinke.

Kljunavci se hranijo z drobnimi živimi ali poginulimi živalmi in rastlinskim drobirjem. Predstavniki družine snežnih bolh (Boreidae), kamor uvrščamo tudi vrsto, ki smo jo našli med snežnimi skakači na Tebru, ne povzročajo nobenih škod. So ena od redkih skupin žuželk, ki jih lahko opazujemo na snegu v zimskem času. Pojavljajo v skupinah (gručah) in jih hitro opazimo zaradi kontrasta temne barve telesa na snegu. Predstavniki te družine predstavljajo predvsem posebnost in zanimivost med žuželkami in zato privlačijo pozornost ljubiteljev narave in raziskovalcev.

V poslanem vzorcu smo odkrili samca snežne bolhe Boreus westwoodi (slika 5, slika 6, slika 7). 


\section{Zahvala}

Določitev vrste Hypogastrura socialis sta opravila prof. F. Janssens (Department of Biology, University of Antwerp, Belgium) in dr. D. Skarzynski (Zoological Institute of Wroclaw University, Wroclaw, Poland), določitev snežne bolhe (Boreus westwoodi) pa prof. dr. D. Devetak (Oddelek za biologijo, Fakulteta za naravoslovje in matematiko Univerze v Mariboru, Maribor). Za pomoč se jim zahvaljujemo.

\section{Viri}

Devetak D. 1988. The distribution of scorpiones (Mecoptera, Insecta) in Slovenia. Biol. vestn., 36, 2: 1-12

Kreithner A. 2001. Über Boreus - Arten aus den Alpen: Taxonomische Charakterisierung und Verbreitung (Insecta, Mecoptera, Boreidae). Ber. nat.-med. Verein Innsbruck, 88: 213-236

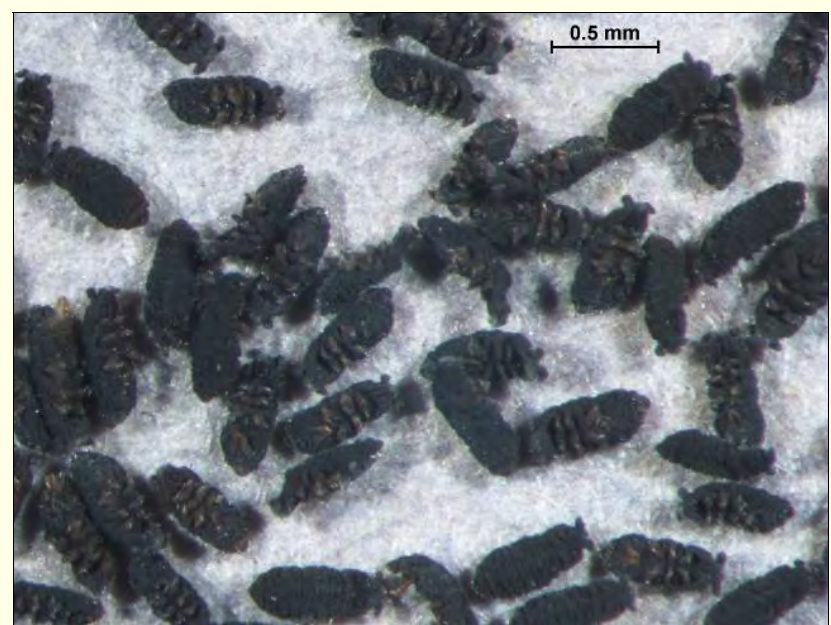

Slika 1. Posušeni snežni skakači iz Tebra nad Črno na Koroškem.

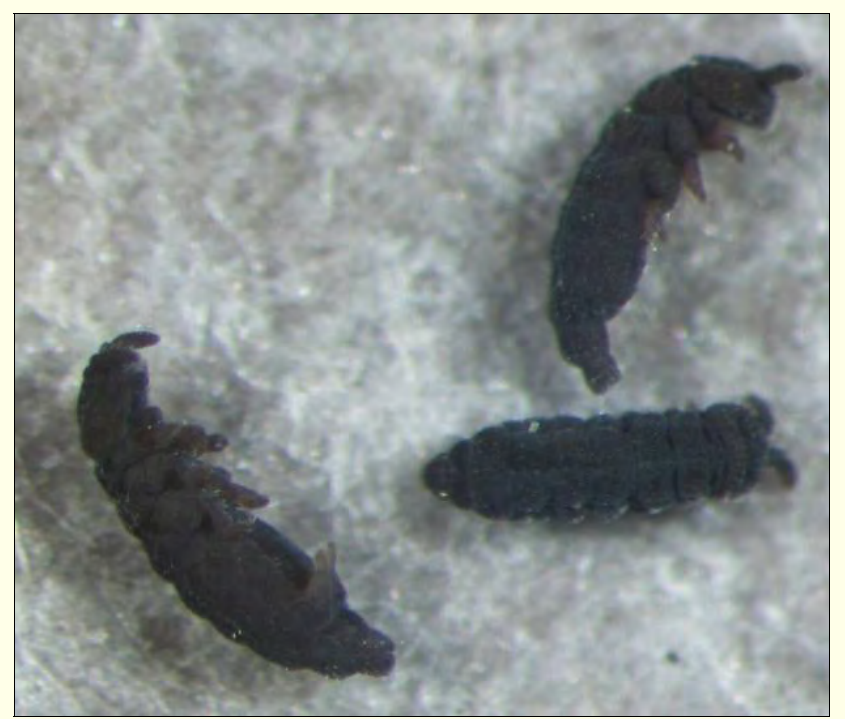

Slika 3. Na zadku skakača (levo spodaj) so dobro opazne skakalne vilice (furka).
Penny N.D. 1977. A systematic study of the family Boreidae (Mecoptera). The University of Kansas Science Bulletin, 51, 5: 141-217

Sket B., Gogala M., Kušor V. 2003. Živalstvo Slovenije. Tehniška založba Slovenije, 664 str.

str.

http://www.collembola.org/ (2. 3. 2010)

${ }^{1}$ Gozdarski inštitut Slovenije, Večna pot 2, 1000 Ljubljana; 2Univerza v Ljubljani, Biotehniška fakulteta, Oddelek za gozdarstvo in obnovljive gozdne vire,Večna pot 83, 1000 Ljubljana; 3Zavod za gozdove Slovenije, Območna enota Slovenj Gradec, Vorančev trg 1, 2380 Slovenj Gradec

*dusan.jurc@gozdis.si

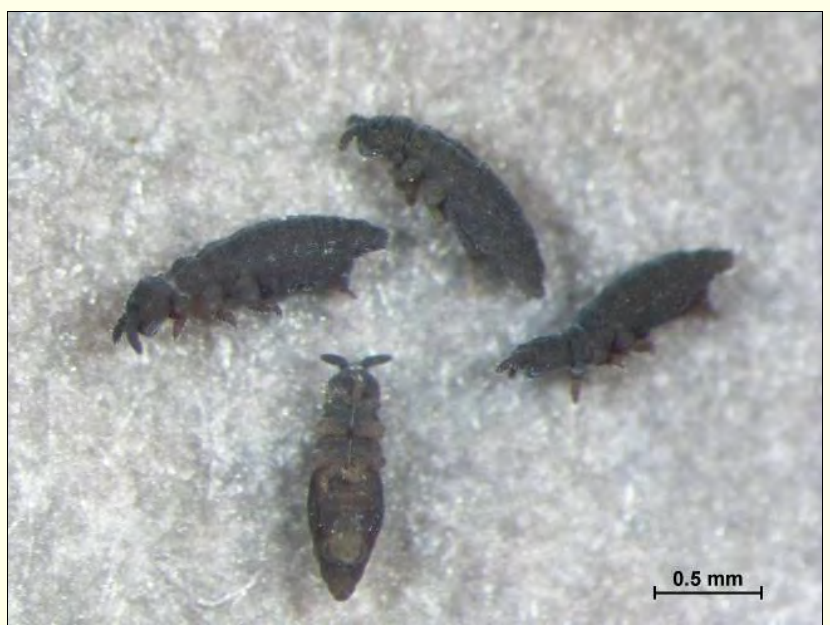

Slika 2. Snežni skakači - od spodaj in od strani.

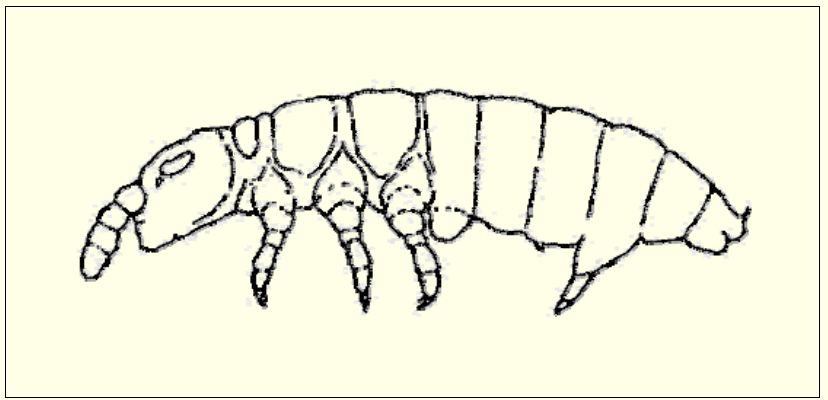

Slika 4. Shematska slika skakača

(vir: http://www.collembola.org) 


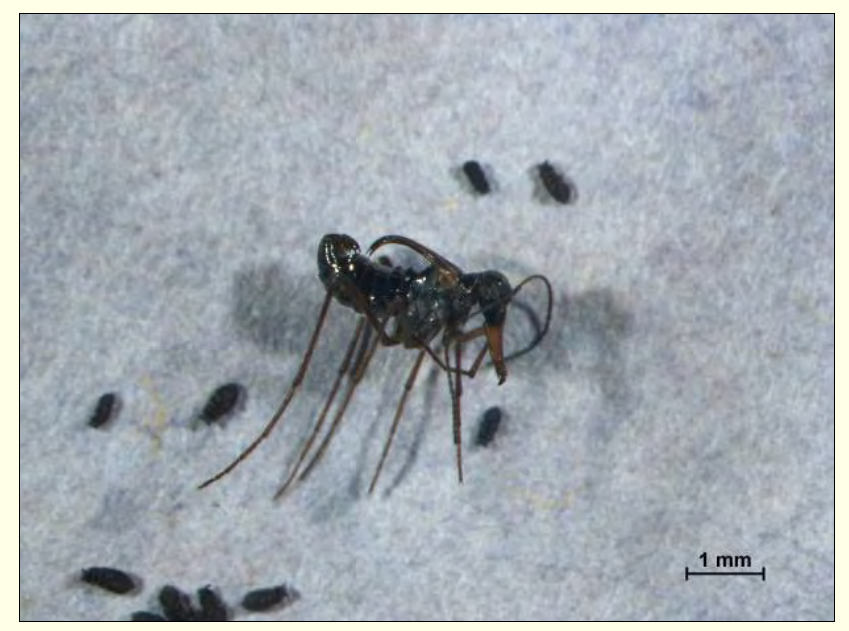

Slika 5. Snežna bolha in skakači.

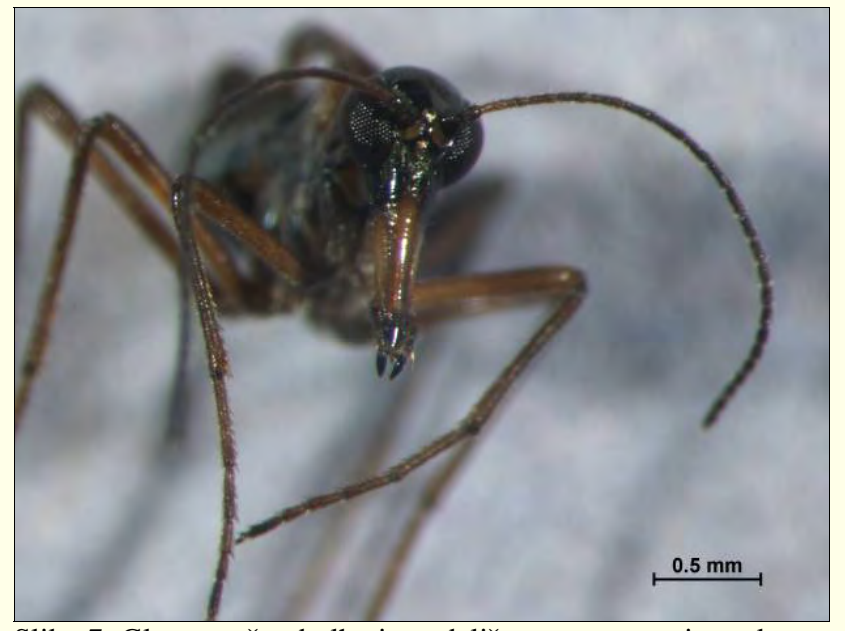

Slika 7. Glava snežne bolhe je podaljšana v rostrum in na koncu je grizalo.

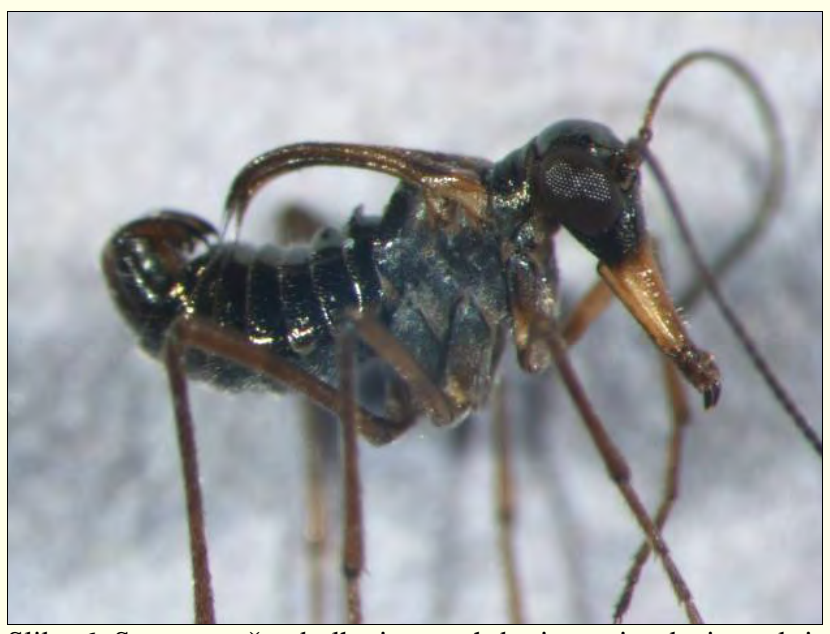

Slika 6. Samec snežne bolhe ima na hrbtni strani reducirana krila.

\section{Tujerodni podlubnik Xylosandrus germanus se širi v gozdovih Sloveni- je}

\section{Maja JURC $^{1 *}$, Zoran Zavrtanik², Matej Reščič ${ }^{3}$}

Podlubnik Xylosandrus germanus (Blandfort, 1894) (Curculionidae: Scolytinae) dolbe rove v lesu iglavcev in listavcev. $\mathrm{V}$ rove zanaša različne glive, ki po eni strani povzročijo trohnenje lesa, po drugi strani pa predstavljajo, skupaj s trohnečim lesom, ustrezno hrano zarodu (zato je skupno ime za te glive "ambrozijske" glive). Običajno ga uvrščamo med sekundarne škodljive organizme (ŠO), včasih pa se pojavi na zdravem drevju in ga poškoduje. Takrat ga imenujemo primarni ŠO.

Gostiteljske drevesne vrste: pojavlja se na več kot 200 drevesnih vrstah kot so npr. breze, bukev, bresti, javori, oreh, hrasti, platane, tulipanovec, vrbe, jablane, jeseni, lipe, koprivovci, pravi kostanj, cedre, bori, brini, smreke, jelke, čuge, octovec, gaber, kosteničevje, ebenovec, sleč, divji kostanj, in še na številnih drugih drevesnih vrstah. V Evropi so poročali o napadih na nas- lednjih drevesnih vrstah: Quercus spp., Juglans regia, Picea abies, Pinus sylvestris, Abies alba. Naseli se lahko na popolnoma zdrava ali že oslabljena drevesa in povzroča njihovo sušenje. S prenosom ambrozijskih gliv v gostiteljska drevesa povzroča okužbe lesa in tako še hitreje razvrednoti les (slika 7).

Xylosandrus germanus izvira iz vzhodne Azije (Japonska, Vietnam, Kitajska). Leta 1932 je bil zanesen v ZDA ter leta 1994 v Kanado. V Evropi so ga odkrili leta 1952 v Nemčiji, leta 1994 v Švici in Belgiji, iz leta 2001 je poročilo o najdbi v Rusiji. V Belgiji se je v enem letu razširil že na 4.000 ha navadne bukve in je začel povzročati poškodbe. Leta 2005 so ga prvič našli na Madžarskem v območju Baranya.

Najdišča v Sloveniji so na Primorskem, Gorenjskem, Notranjskem in v okolici Ljubljane, po dostopnih podatkih je lokacij 6 (slika 1). Prvič je bil najden 